EUROPA REGIONUM TOM XXVIII ROK 2016

DOI : $10.18276 /$ er.2016.28-12

WIESŁAW M. MAZIARZ

Uniwersytet Szczeciński

\title{
Ekonomia społeczna w Polsce
}

\section{Wprowadzenie}

$\mathrm{W}$

ykluczenie społeczne jest bardzo istotnym zagadnieniem współczesnej cywilizacji. Przyjmuje się, iż w Polsce dotyczy ono 27,2\% ogółu ludności, natomiast $\mathrm{w}$ przypadku całej Unii Europejskiej problem ten jest udziałem $24,2 \%$ mieszkańców ${ }^{1}$. Zjawisko to stwarza bardzo poważne implikacje o charakterze społecznym i gospodarczym, zmuszając państwa do podejmowania działań mających na celu ponowną integrację wykluczonych ze społeczeństwem. Bardzo często wykluczenie jest powiązane $\mathrm{z}$ ubóstwem, co stanowi dodatkowe utrudnienie w przypadku inkluzji społecznej. Narzędzia stosowane zazwyczaj w takich sytuacjach mają naturę finansowego wspomagania potrzebujących obywateli. Powinny mieć one jednak charakter krótkookresowy, bowiem w długim okresie mogą demoralizować i zniechęcać do włączenia się w struktury społeczne oraz podjęcia pracy. W związku z tym konieczne jest wypracowanie bardziej efektywnego modelu przeciwdziałania wykluczeniu, który oparty byłby na stworzeniu osobom marginalizowanym warunków do wzięcia odpowiedzialności za los swój i rodziny. Chodzi w tym przypadku generalnie o działania mające na celu klasyczne „danie wędki a nie ryby”. Rozwiązanie problemu wykluczonych w proponowanym ujęciu staje się możliwe w przypadku praktycznego wykorzystania narzędzi ekonomii społecznej.

${ }^{1}$ Krajowy Program Przeciwdziałania Ubóstwu i Wykluczeniu Społecznemu 2020. Nowy wymiar aktywnej integracji, Ministerstwo Pracy i Opieki Społecznej, Warszawa 2014. s.5. 


\section{Pojęcie ekonomii społecznej}

Termin ekonomia społeczna pojawił się w literaturze przedmiotu w Polsce stosunkowo niedawno, natomiast działania, które przyjęto $\mathrm{z}$ tym określeniem wiązać, były przedmiotem aktywności społeczno-gospodarczej już nawet w wieku $\mathrm{XIX}^{2}$. W literaturze przedmiotu nie wykształciła się dotychczas powszechnie definicja ekonomii społecznej. Trzeba stwierdzić, iz różnice w podejściu do interpretacji tego zagadnienia powodują, iż trudno jest określić ostre ramy kompetencyjne ekonomii społecznej. Samo pojęcie ekonomia społeczna jest także przez znaczną część znawców przedmiotu kontestowane i często zastępowane pojęciami przedsiębiorczość społeczna, gospodarka społeczna czy przedsięwzięcie o społecznej wartości dodanej, chociaż na gruncie istniejących koncepcji terminologicznych trudno uznać te pojęcia za synonimiczne. Niemniej dokonanie przeglądu istniejących definicji jest konieczne, aby uzyskać przynajmniej ogólny pogląd istoty ekonomii społecznej. Według najczęściej przedstawianego ujęcia ekonomia społeczna to „sfera aktywności obywatelskiej, która poprzez działalność ekonomiczną i działalność pożytku publicznego służy: integracji zawodowej i społecznej osób zagrożonych marginalizacją społeczną, tworzeniu miejsc pracy, świadczeniu usług społecznych użyteczności publicznej (na rzecz interesu ogólnego) oraz rozwojowi lokalnemu"3. Przedstawiona koncepcja definicyjna przedstawia istotę ekonomii społecznej poprzez wyartykułowanie przedmiotowego zakresu jej funkcjonowania. W innym ujęciu termin ekonomia społeczna jest definiowany jako ,narzędzie mobilizacji ekonomicznej i społecznej zaniedbanych społeczności lokalnych (czy też obszarów) oraz jako formułę zwiększenia uczestnictwa ich członków (mieszkańców) w wymianie gospodarczej i życiu publicznym" ${ }^{4}$. W tym wypadku ekonomia społeczna jest rozumiana W sensie instrumentalnym, jednak bez określenia podmiotu lub podmiotów, w gestii których się powinna znajdować. Można przyjąć intuicyjnie, iż podmiotem wykorzystującym instrumentalnie ekonomię społeczną jest państwo, reali-

\footnotetext{
${ }^{2}$ Termin ,economie socjale” powstał w XIX wieku we Francji i w wieku XX nastąpiło jego rozpowszechnienie. Wykorzystywany $\mathrm{w}$ Polsce zwrot ekonomia społeczna jest thumaczeniem francuskiego pierwowzoru. Ponieważ jednak w języku francuskim termin „economie” posiada kilka znaczeń, w polskojęzycznej literaturze przedmiotu istnieje szereg określeń tego zjawiska społeczno-gospodarczego.

${ }^{3}$ Krajowy Program Rozwoju Ekonomii Społecznej, Ministerstwo Pracy i Polityki Społecznej, Monitor Polski z dnia 24 września 2014 r., poz. 811.

${ }^{4}$ T. Kazimierczak, M. Rymsza, Kapitat społeczny. Ekonomia społeczna, Instytut Spraw Publicznych, Warszawa 2007, s. 11.
} 
zujące swoje kompetencje społeczne oraz obowiązki w stosunku do obywateli. Takie rozumowanie burzy zaprezentowanie podejścia koncepcyjnego, które przyjmuje, iż „ekonomia społeczna zajmuje się aktywnością społeczną nie przynależną rynkowi i państwu" i mającą względem nich charakter komplementar$n y^{5}$. To ujęcie wskazuje przede wszystkim na oddolny i lokalny charakter ekonomii społecznej, jak również na działalność niepodlegającą regułom rynkowym. Komplementarność zaś rozpatrywać należy w kontekście zaspokajania przez ekonomię społeczną potrzeb społecznych, których zarówno państwo, jak i rynek spełnić nie są w stanie. Kolejna koncepcja definicyjna przedstawia ekonomię społeczną jako ,sektor gospodarki, w którym organizacje są zorientowane na społeczną użyteczność, a wypracowana przez nie nadwyżka służy realizacji celu społecznego. Taka ich misja wynika z i jest chroniona przez autonomie zarządzania, demokratyczne decydowanie oraz lokalne zakorzenienie tych orga-

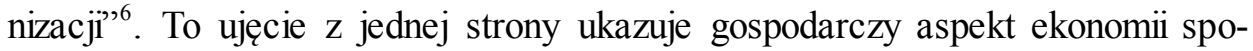
łecznej, natomiast $z$ drugiej silnie podkreśla jej wymiar społeczny. Pozwala to spojrzeć na ekonomię społeczną jako swoisty byt łączący działalność gospodarczą z określoną i społecznie akceptowaną misją.

Przedstawiony powyżej przegląd definicji terminu ekonomia społeczna nie daje jednoznacznej wykładni jak ten termin należy rozumieć. Można natomiast wykorzystać przytoczone koncepcje pojęciowe do określenia zestawu cech, które są immanentnie związane $\mathrm{z}$ ekonomią społeczną. Można zatem przypisać tej kategorii społeczno-gospodarczej następujące cechy:

- oddolny charakter inicjatyw,

- lokalny obszar działania.

- nakierowanie na kontekst społeczny,

- niezależność,

- demokratyczny system decyzyjny,

- solidarność,

- partycypacyjna forma działalności,

- w miarę niekonkurencyjny charakter prowadzonej działalności gospodarczej.

${ }^{5}$ W. Kwaśnicki, Gospodarka społeczna z perspektywy ekonomii liberalnej, Trzeci sektor, 2005, $\mathrm{nr} 2$.

${ }^{6}$ J. Hausner, Ekonomia społeczna jako kategoria rozwoju, w: Ekonomia społeczna a rozwój, red. Hausnera J., Małopolska Szkoła Administracji Publicznej Uniwersytetu Ekonomicznego w Krakowie, Kraków 2007, s. 14. 
Kontynuując rozważania definicyjne związane z pojęciem ekonomia społeczna, należy stwierdzić, iż powszechną praktyką w literaturze przedmiotu są próby definiowania ekonomii społecznej w ujęciu instytucjonalnym, przez pryzmat organizacji, które w jej obszarze prowadzą działalność, co wiąże się z koniecznością sprecyzowania pojęcia podmiot ekonomii społecznej. CMAF-CEP ${ }^{7}$ przyjęła, iż ekonomia społeczna obejmuje takie organizacje jak ,spółdzielnie, towarzystwa ubezpieczeń wzajemnych, stowarzyszenia i fundacje" ${ }^{\text {. }}$. W przypadku Polski za podmioty ekonomii społecznej przyjęto uznawać spółdzielnie pracy, spółdzielnie inwalidów i niewidomych, zakłady aktywności zawodowej, spółki non profit, spółdzielnie socjalne, kościelne osoby prawne, centra integracji społecznej, warsztaty terapii zajęciowej oraz kluby integracji społecznej. Przedstawiony powyżej zakres podmiotów funkcjonujących w ramach ekonomii społecznej jest bardzo szeroki. Nie pozwala to znaleźć podstawy do wykreowania cech, którymi te organizacje by się charakteryzowały. W sposób szczególny wszelkie podejścia klasyfikacyjne utrudnia kwestia podmiotów integracji społecznej, które w przypadku gdyby były tworzone przez instytucje państwowe lub samorządowe, nie powinny być traktowane jako podmioty ekonomii społecznej. Zresztą oceniając przyjęty $\mathrm{w}$ regulacjach polskich model układu podmiotowego ekonomii społecznej należy do niego podejść mocno krytycznie. Wydaje się, iż konieczne jest w literaturze przedmiotu, ale także na niwie praktyki, ograniczenie zakresu organizacji uznanych za podmioty ekonomii społecznej. Istotne byłoby zasugerowanie, iż jedynie przedsiębiorstwa społeczne powinny mieć taki status. Podstawą takiego postulatu powinno być stwierdzenie, iż pozostałe podmioty nie prowadząc działalności o charakterze gospodarczym mogą stanowić co najwyżej otoczenie ekonomii społecznej i ich funkcjonowanie ma zasadniczo kontekst socjalny. Problematyka definiowania przedsiębiorstw społecznych to kolejny ważny aspekt ekonomii społecznej. W tym zakresie istnieje swoista dowolność w kształtowaniu koncepcji pojęciowych do rozumienia omawianego terminu i jego zakresu przedmiotowego. Znaczna część definicji ma charakter mocno ogólny i nieostry, nie wnosząc nic nowego do teorii przedmiotu. Inne z kolei koncentrują się wyłącznie na przedstawieniu cech przedsiębiorstwa społecznego lub określeniu przedmiotowego zakresu jego funkcjonowania. Przy-

\footnotetext{
${ }^{7}$ CMAF - CEP oznacza Europejską Stałą Konferencję Spółdzielni, Towarzystw Ubezpieczeń Wzajemny ch, Organizacji i Fundacji.

${ }^{8}$ B. Roelants, C.S. Bajo, Rozszerzenie ekonomii społecznej, w: Materiały konferencji Ekonomia Społeczna 2002., pod red. Roelant B., Praga 2002, s. 6
} 
kładowo w projekcie ustawy o przedsiębiorczości społecznej i wspieraniu ekonomii społecznej ${ }^{9}$ brak jest konkretnej definicji pojęcia przedsiębiorstwo społeczne. Przedstawiony został jedynie w art. 5 możliwy do realizacji, zamknięty zakres działalności gospodarczej przedsiębiorstwa społecznego. Wymienione zostały sfera reintegracji zawodowej osób wykluczonych (bezrobotnych, bezdomnych, uzależnionych od alkoholu, środków odurzających, chorych psychicznie, zwalnianych z zakładów karnych, uchodźców, osób niepełnosprawnych, itp.) oraz sfera przedmiotowa działalności przedsiębiorstw społecznych (pomoc społeczna, opieka nad dziećmi, prowadzenie przedszkoli niepublicznych i innych form wychowania przedszkolnego, ochrona zdrowia psychicznego oraz wsparcie osób niepełnosprawnych). W omawianej ustawie, w art. 2, wymieniono podmioty ekonomii społecznej, gdzie przedsiębiorstwo społeczne, zostało oddzielone od innych form społecznej aktywności gospodarczej (np. spółdzielni socjalnych). Taki zabieg nie ma żadnych podstaw merytorycznych, wynika jedynie z zasadniczego celu niniejszej ustawy, którym jest wsparcie dla precyzyjnie określonych form działalności oraz grup osób wykluczonych. W myśl tej ustawy uzyskanie statusu przedsiębiorstwa społecznego wiąże się z określonymi preferencjami o charakterze finansowym (np. dotacje, preferencyjne pożyczki, obniżki podatku od nieruchomości oraz ulgi w podatku dochodowym). Cel ustawy deprecjonuje ją jako źródło podejść definicyjnych związanych z pojęciem przedsiębiorstwa społecznego.

Bardziej precyzyjną definicję przedsiębiorstwa socjalnego przedstawiono w brytyjskiej ustawie o Przedsiębiorstwach Interesu Publicznego z 2005 r., gdzie podmioty te zostały przedstawione jako „organizacje pożytku publicznego, które dążą do zaspokojenia potrzeb społecznych, poprzez narzucenie sobie, przynajmniej częściowo, ograniczeń non profit i poświęcenie swoich środków i zasobów na rzecz działalności zorientowanej społecznie" ${ }^{10}$. Rozpatrując inne podejścia w zakresie definiowania przedsiębiorstw socjalnych warto przedstawić ujęcie prezentujące podstawowe komponenty tego pojęcia. Należy do nich zaliczyć ${ }^{11}$ :

${ }^{9}$ www.ekonomiaspoleczna.pl

${ }^{10}$ C. Borzaga, S. Depedri, E. Tortia, Organizacyjne zróżnicowanie gospodarki rynkowej a rola spółdzielni $i$ przedsiębiorstw społecznych: apel o pluralizm ekonomiczny, Ekonomia społeczna, nr 3, 2013.

${ }^{11}$ J. Hausner, N. Laurisz, S. Mazur, Przedsiębiorstwo spoteczne - konceptualizacja, w: Zarzadzanie podmiotami ekonomii społecznej, pod red. Hausnera J., Małopolska Szkoła Administracji Publicznej Uniwersytetu Ekonomicznego w Krakowie, Kraków 2007, s. 13-14. 
- wytwarzanie produktów lub usług wiążące się z ryzykiem gospodarczym i ekonomiczną weryfikacją efektów tej działa lności,

- ukierunkowanie działalności na integrację społeczną w skali danej społeczności lokalnej,

- podporządkowanie stosunków własnościowych interesom interesariuszy,

- kultura zarządzania osadzona na partnerstwie i partycypacji,

- demokratyczna kontrola ze strony interesariuszy.

Podobnie do problematyki definiowania przedsiębiorstw społecznych podeszła organizacja EMES (European Research Network). Stworzyła ona model identyfikowania przedsiębiorstw społecznych, przyjmuje, iż podmioty te powinny charakteryzować się określonymi aspektami ekonomicznymi i społecznymi. Do oceny wymiaru ekonomicznego przyjęto następujące elementy ${ }^{12}$ :

- ciągły charakter prowadzonej działalności gospodarczej,

- wysoki poziom autonomii podmiotu,

- podejmowanie przez podmiot ryzyka ekonomicznego,

- przynajmniej w minimalnym stopniu odpłatne zatrudnienie pracowników.

W przypadku oceny wymiaru społecznego przedsiębiorstwa społecznego uwzględniono $^{13}$ :

- oddolny charakter inicjatywy dotyczącej powstania organizacji,

- demokratyczny system decyzyjny,

- partycypacyjny charakter prowadzonej działalności,

- wyraźnie określony cel społeczny,

- ograniczony podział zysków.

Kończąc rozważania poświęcone przedsiębiorstwom społecznym, należy enumeratywnie wypisać podmioty ekonomii społecznej, które z tym pojęciem należy łączyć. Należy przyjąć, iż przedsiębiorstwami społecznymi są spółdzielnie socjalne i prowadzące działalność gospodarczą fundacje i stowarzyszenia.

Przedstawione rozważania dotyczące przedsiębiorstwa społecznego wzbogaciły zakres pojmowania ekonomii społecznej. Przede wszystkim trzeba stwierdzić, iż ekonomia społeczna to obszar działań o charakterze gospodarczym, podporządkowany ideowo realizacji powiązany z określoną ideą społeczną.

${ }^{12}$ C. Borzaga, J. Defourny, The Emergence of Social Enterprise, Routledge, London 2001, s. $16-18$

${ }^{13}$ Ibidem, s. 16-18. 


\section{Realizacja funkcji ekonomii społecznejw społeczeństwiei gospodarce na przykładzie Polski}

Znaczenie ekonomii społecznej w poszczególnych krajach jest w znacznym stopniu zróżnicowane. W państwach ,starej” Unii Europejskiej, Australii oraz w Stanach Zjednoczonych istnieją silne tradycje solidarności i samopomocy, w związku z czym ekonomia społeczna stanowi tam dość silny sektor gospodarki. W Polsce $\mathrm{i}$ innych krajach postsocjalistycznych idee powiązane $\mathrm{z}$ ekonomią społeczną zostały w znacznym stopniu wypaczone w ciągu 45 lat transformacji socjalistycznej. W Unii Europejskiej złożonej z 25 państw sektor ekonomii społecznej wytwarza średnio około $10 \%$ PKB, przy $10 \%$ udziale w zatrudnieniu ${ }^{14}$. Do przedstawionych wartości podejść należy ostrożnie, bowiem zestawienie danych z poszczególnych państw, ze względu na rozbieżności w klasyfikowaniu organizacji i obszarów działalności ekonomii społecznej, mogą nie być w pełni kompatybilne. Rozważając problematykę znaczenia ekonomii społecznej w Polsce należy zastanowić się nad funkcjami, które ona spełnia $\mathrm{w}$ odniesieniu do sfery społecznej i gospodarczej. W literaturze przedmiotu przypisuje się ekonomii społecznej następujące funkcje ${ }^{15}$ :

- pobudzanie aktywności obywatelskiej opartej na solidarności i osobistym zaangażowaniu,

- generowanie miejsc pracy o wysokiej jakości i polepszenie poziomu życia,

- pobudzenie rozwoju lokalnego,

- wzmacnianie spójności społecznej.

Wynika $\mathrm{z}$ nich, iż ekonomia społeczna powinna pełnić rolę swoistego czynnika indukcyjnego, pobudzającego różnego rodzaju pokłady energii tkwiące z układach społecznych, celem rozwiązania określonych problemów o charakterze społecznym. W praktyce funkcjonowania ekonomii społecznej w poszczególnych państwach świata wygląda to różnie. Wyjaśnienie tej problematyki wymaga przede wszystkim przedstawienia i omówienia teoretycznych scenariuszy rozwoju ekonomii społecznej możliwych do wykorzystania na niwie praktyki. Scenariusze te można określić jako ${ }^{16}$ :

\footnotetext{
${ }^{14}$ W. Zarzycki, Ekonomia spoleczna - co to takiego? http//www.pogotowiespoleczne.org.p 1/index.php nr 1, 2007.

${ }^{5}$ B. Szopa, Ekonomia spoteczna z perspektywy ekonomii tradycyjnej, Ekonomia Społeczna,

${ }^{16} \mathrm{~K}$. Birkholzer, Lokalny rozwój gospodarczy i jego potencjat, w: Z teorii i praktyki gospodarki społecznej, pod red. Leś E. i Oldak M., tom I, Collegium Civitas, Warszawa 2006, s. 27-28.
} 
- „rozwój od góry”, w którym państwo jest głównym inicjatorem powstawania podmiotów ekonomii społecznej stwarzając im dogodne warunki rozwoju o charakterze regulacyjnym i finansowym,

- „rozwój z zewnątrz”, pobudzany przez przedsiębiorstwa czy instytucje (inwestorów zewnętrznych), które wspomagają podmioty ekonomii społecznej wnosząc określone zasoby, np. know how, środki finansowe,

- „czekanie i obserwowanie”, w którym potencjalni inicjatorzy podmiotów ekonomii społecznej pozostają pasywni oczekując na konkretne działania ze strony organów samorządowych i państwowych.

- „rozwój od wewnątrz”, w którym inicjatywa tworzenia podmiotów ekonomii społecznej wychodzi od członków lokalnych społeczności, szukających perspektyw rozwoju, zarówno indywidualnego, jak i grupowego.

Przedstawione ujęcie scenariuszy kształtowania ekonomii społecznej z pewnością nie jest doskonałe ale stanowi dobrą podstawę teoretyczną do rozważań nad praktyczną naturą gospodarki społecznej. Przede wszystkim trzeba zwrócić uwagę na fakt, iż scenariusz ,czekanie i obserwowanie” nie umożliwia realizacji żadnej z przedstawionych funkcji ekonomii społecznej. Nie zakłada bowiem aktywnego uczestnictwa obywateli w procesach gospodarczych i społecznych państwa. Niemniej jednak takie właśnie zachowania są udziałem znacznego odsetka grup wykluczonych w społeczeństwie polskim. Scenariusz „rozwój od góry” także nie ma nic wspólnego z ideą ekonomii społecznej. Należy go uznać za odmianę polityki społecznej realizowanej przez państwo itrudno w tym ujęciu dopatrzyć się pobudzania aktywności obywatelskiej opartej na solidarności, osobistego zaangażowania czy wzmacniania spójności społecznej. Ten scenariusz nie jest realizowany wPolsce, ale jest oczekiwany przez znaczną część wykluczonych, szczególnie tych pozbawionych inicjatywy i nastawionych roszczeniowo. Szczególnie oczekiwanym scenariuszem jest opcja „rozwój od wewnątrz” ponieważ wiąże się on z kluczowymi dla ekonomii społecznej problemami, takimi jak aktywna partycypacja, zaangażowanie, dbałość o interes własny i społeczny, niezależność od różnych instytucji. Tylko taki model ekonomii społecznej spełnia wszystkie założone funkcje. Niemniej jednak ten scenariusz rozwoju ekonomii społecznej jest w Polsce stosunkowo rzadkim zjawiskiem. Ostatni scenariusz określony jako „rozwój z zewnątrz” jest tym, który występuje w Polsce, ale także w większości państw Unii Europejskiej. Wynika to z faktu, iż podmioty ekonomii społecznej są $\mathrm{w}$ poważnym stopniu powiązane różnymi formami relacji z podmiotami samorządowymi czy państwowymi. W takich warunkach bardzo trudno jest mówić o pełnej niezależności i samostanowieniu. Gdyby 
popatrzeć na działalność podmiotów ekonomii społecznej w Polsce przez pryzmat finansowania, to trzeba stwierdzić, iż ma ono charakter hybrydowy, ze szczególnym uwzględnieniem środków publicznych. Ekonomia społeczna w tym ujęciu z pewnością jest ułomna, ale może być skuteczna. Konstatacja oparta na znajomości praktycznej strony ekonomii społecznej w Polsce prowadzi do konkluzji, iż ta forma działalności społeczno-gospodarczej praktycznie nie byłaby możliwa do realizacji bez finansowania zewnętrznego. Pozostaje zatem pytanie czy jest sens wydatkowania środków samorządowych lub państwowych na funkcjonowanie podmiotów ekonomii społecznej. Odpowiadając należy przyjąć, iż pomiędzy finansowaniem i nnymi formami wsparcia ekonomii społecznej a aktywnością obywatelską występuje efekt synergii, który w znacznym stopniu przewyższa zaangażowane z ekonomię społeczną środki.

\section{Poziom rozwoju ekonomii społecznej w Polsce oraz w województwie zachodniopomorskim}

Precyzyjne określenie pozycji ekonomii społecznej w Polsce i jej wpływu na funkcjonowanie sfery gospodarczej i społecznej w Polsce jest przedsięwzięciem bardzo trudnym. Jest to przede wszystkim konsekwencją braku wiarygodnych i pełnych danych statystycznych dotyczących działalności podmiotów ekonomii społecznej. Trzeba stwierdzić wręcz, iż nikt nie posiada kompletnej wiedzy, ile takich podmiotów w Polsce jest, i ile z nich w sposób aktywny działa. Praktycznie jedynym dokumentem, który można wykorzystać do analizy podmiotów ekonomii społecznej jest publikacja GUS pt. „Trzeci sektor w Polsce. Stowarzyszenia, fundacje, społeczne podmioty wyznaniowe, organizacje samorządu zawodowego, gospodarczego i pracodawców w 2012 roku”. Dane zaprezentowane w tej części artykułu będą pochodziły z tego źródła. $Z$ informacji zawartych w tej publikacji wynika, iż w Polsce w 2012 r. (brak późniejszych danych) aktywną działalność prowadziło 83,5 tys. organizacji trzeciego sektora, $w$ tym $^{17}$ :

- 69,5 tys. ( $83 \%$ populacji) stowarzyszeń i podobnych organizacji spotecznych,

- 8,5 tys. (10\%) fundacji,

- 3,6 tys. (4\%) organizacji samorządu gospodarczego, zawodowego i pracodawców,

${ }^{17}$ Trzeci sektor $w$ Polsce. Stowarzyszenia, fundacje, spoleczne podmioty wyznaniowe, organizacje samorządu zawodowego, gospodarczego i pracodawców w 2012 r., GUS, Warszawa 2014 
- $\quad 1,8$ tys. (2\%) spolecznych podmiotów wyznaniowych.

Oczywiście $\mathrm{w}$ żadnej mierze nie można twierdzić, iż organizacje trzeciego sektora stanowią podmioty ekonomii społecznej. Można do nich zaliczyć tylko te organizacje, które podjęły obok działalności statutowej, działalność gospodarczą. $\mathrm{Z}$ dostępnych danych wynika, iż $75 \%$ organizacji trzeciego sektora prowadziło wyłącznie nieodpłatną działalność statutową a jedynie 7\% organizacji rozwinęło działalność gospodarczą. Może to oznaczać, iż w Polsce do podmiotów ekonomii społecznej można zaliczyć około 5845 organizacji trzeciego sektora. Zaprezentowane dane pozwalają na określenie skali rozwoju podmiotów ekonomii społecznej w województwie zachodniopomorskim wywodzących się z trzeciego sektora. Ogółem w tym województwie w 2012 było około 3200 organizacji trzeciego sektora, w tym:

- 2780 stowarzyszeń i podobnych organizacji społecznych,

- 255 fundacji,

- 108 organizacji samorządu gospodarczego, zawodowego i pracodawców,

- 54 społecznych podmiotów wyznaniowych.

Do organizacji ekonomii społecznej można przypisać tylko $224 \mathrm{z}$ nich.

Poza wymienionymi organizacjami jako podmioty ekonomii społecznej należy także klasyfikować spółdzielnie socjalne, których ogółem w Polsce zgodnie ze stanem na maj 2014 r. było 1067, z tego w województwie zachodniopomorskim $52^{18}$. Według innych danych, prezentowanych na koniec 2014 r. ponad 1300 spółdzielni socjalnych, $\mathrm{z}$ tego $\mathrm{w}$ województwie zachodniopomorskim $63^{19}$. Tak znaczny przyrost liczby spółdzielni socjalnych należy powiązać z ostatnim okresem funkcjonowania projektu Ośrodki Wsparcia Ekonomii Społecznej realizowanego w ramach Programu Operacyjnego Kapitał Ludzki, który wprowadzał atrakcyjne dotacje na założenie spółdzielni socjalnej. Potwierdza to zawartą wcześniej myśl, iż w Polsce rozwój ekonomii społecznej kształtuje się według scenariusza „rozwój z zewnątrz”. Przedstawiony stan spółdzielni socjalnych nie jest równoważny z liczbą podmiotów aktywnie prowadzących działalność gospodarczą. Znaczna liczba spółdzielni jest bowiem w stanie likwidacji lub upadłości, czego nie wykazują statystyki. Podsumowując otrzymane wyniki można przyjąć, iż w Polsce istnieje około 7,2 tys. podmiotów ekonomii społecznej, z tego na terenie województwa zachodniopomorskiego około 290. Są to wartości szacunkowe oparte na niepelnych danych i należy je w związku z tym traktować z należytą ostrożnością. Biorąc pod uwagę, iż liczba podmiotów prowadzących

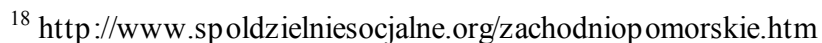

${ }^{19} \mathrm{http}: / /$ ozrss.pl/category/katalog/wojewodztwo/zachodniop omorskie/
} 
działalność gospodarczą wynosi $1,78 \mathrm{mln}$ firm $^{20}$, to udział podmiotów ekonomii społecznej w tej grupie wynosi około $0,4 \%$. Jest to wartość w sposób drastyczny odbiegający od poziomu ukształtowanego w Unii Europejskiej. Oznacza to, że ekonomia społeczna w Polsce jest dopiero na początku drogi i konieczne są konkretne działania, ze strony różnych instytucji, aby ten stan rzeczy poprawić.

\section{Podsumowanie}

Ekonomia społeczna w Polsce jest zjawiskiem stosunkowo nowym, niejednoznacznie rozumianym ale stwarzającym atrakcyjne perspektywy dla wzrostu aktywności społeczno-gospodarczej osób wykluczonych. Niemniej na chwilę obecną ekonomia społeczna w Polsce ma marginalne znaczenie i konieczne są skorelowane działania o charakterze edukacyjnym, promocyjnym i finansowym, aby ten stan rzeczy uległ zmianie. Szczególnie niekorzystnie kształtuje się sytuacja ekonomii społecznej w województwie zachodniopomorskim, co jest konsekwencją roszczeniowo nastawionych grup wykluczonych oraz niechęcią do wszelkich zmian.

\section{Bibliografia}

Birkholzer K., Lokalny rozwój gospodarczy i jego potencjat, w: (red.) E. Leś, M. Oldak Z teorii i praktyki gospodarki społecznej, , tom I, Collegium Civitas, Warszawa 2006, s. 27-28.

Borzaga C., Defourny J., The Emergence of Social Enterprise, Routledge, London 2001, s. $16-18$.

Borzaga C., Depedri S., Tortia E., Organizacyjne zróżnicowaniegospodarki rynkowej a rola spółdzielni i przedsiębiorstw społecznych: apel o pluralizm ekonomiczny, Ekonomia społeczna, nr 3, 2013.

Hausner J., Ekonomia spolecznajako kategoria rozwoju, w: Ekonomia społeczna a rozwój, J. Hausnera (red.), Małopolska Szkoła Administracji Publicznej Uniwersytetu Ekonomicznego w Krakowie, Kraków 2007, s. 14.

Hausner J., Laurisz N., Mazur S., Przedsiębiorstwo spoleczne-konceptualizacja, w: J. Hausnera (red.),Zarządzanie podmiotami ekonomii społecznej, Małopolska Szkoła Administracji Publicznej Uniwersytetu Ekonomicznego w Krakowie, Kraków 2007, s. 1314.

Kazimierczak T., Rymsza M., Kapitat spoleczny. Ekonomia społeczna, Instytut Spraw Publicznych, Warszawa 2007, s. 11.

Krajowy Program Rozwoju Ekonomii Społecznej, Ministerstwo Pracy i Polityki Społecznej, Monitor Polski z dnia 24 września 2014, poz. 811.

${ }^{20}$ www.forbes.pl 
Kwaśnicki W., Gospodarka społeczna z perspektywy ekonomii liberalnej, Trzeci sektor, nr 2, 2005.

Roelants B., Bajo C.S., Rozszerzenie ekonomii społecznej, w: B. Roelant (red.), Materiały konferencji Ekonomia Społeczna 2002., Praga 2002, s. 6.

Szopa B., Ekonomia społeczna z perspektywy ekonomii tradycyjnej, Ekonomia Społeczna, nr 1, 2007.

Trzeci sektor w Polsce. Stowarzyszenia, fundacje, społeczne podmioty wyznaniowe, organizacje samorzadu zawodowego, gospodarczego i pracodawców w 2012 r., GUS, Wars zawa 2014.

Zarzycki W., Ekonomia społeczna - co to takiego? http://www.pogotowiespoleczne. org.pl/index.php

\section{Social economy in Poland}

\section{Summary}

The article presents fundamental issues related to the essence of the social economy. An review of the social economy definition according to different approaches was made. The Author referred to the notion and the ranking of social economy entities. Also the features, which those operators should be characterized were pointed out. Subs equently the attention to the role of the social economy in the society and the economy was paid. At the end some information in relation to the development of the social economy in Poland and on the area of the West Pomeranian region were presented.

Translated by Wiestaw M. Maziarz 